\title{
High Refractive Index Silica-Titania Films Fabricated via the Sol-Gel Method and Dip-Coating Technique-Physical and Chemical Characterization
}

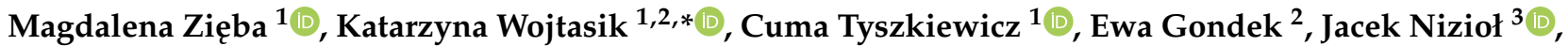 \\ Katarzyna Suchanek ${ }^{2}$ (D), Michał Wojtasik ${ }^{4}$, Wojciech Pakieła ${ }^{5}$ and Paweł Karasiński ${ }^{1, *(\mathbb{D})}$
}

1 Department of Optoelectronics, Silesian University of Technology, B. Krzywoustego 2, 44-100 Gliwice, Poland; magdalena.zieba@polsl.pl (M.Z.); cuma.tyszkiewicz@polsl.pl (C.T.)

2 Department of Physics, Cracow University of Technology, Podchorążych 1, 30-084 Kraków, Poland; egondek@pk.edu.pl (E.G.); katarzyna.suchanek@pk.edu.pl (K.S.)

3 Faculty of Physics and Applied Computer Science, AGH University of Science and Technology, al. Mickiewicza 30, 30-059 Krakow, Poland; niziol@agh.edu.pl

4 Oil and Gas Institute—National Research Institute, Lubicz 25A, 31-503 Krakow, Poland; wojtasik@inig.pl

5 Faculty of Mechanical Engineering, Institute of Engineering Materials and Biomaterials, Silesian University of Technology, ul. Konarskiego 18a, 44-100 Gliwice, Poland; wojciech.pakiela@polsl.pl

* Correspondence: katarzyna.wojtasik@pk.edu.pl (K.W.); pawel.karasinski@polsl.pl (P.K.)

\section{check for} updates

Citation: Zięba, M.; Wojtasik, K.; Tyszkiewicz, C.; Gondek, E.; Nizioł, J.; Suchanek, K.; Wojtasik, M.; Pakieła, W.; Karasiński, P. High Refractive Index Silica-Titania Films Fabricated via the Sol-Gel Method and Dip-Coating Technique-Physical and Chemical Characterization. Materials 2021, 14, 7125. https:// doi.org/10.3390/ma14237125

Academic Editor: Alain Walcarius

Received: 28 October 2021

Accepted: 18 November 2021

Published: 23 November 2021

Publisher's Note: MDPI stays neutral with regard to jurisdictional claims in published maps and institutional affiliations.

Copyright: (c) 2021 by the authors. Licensee MDPI, Basel, Switzerland. This article is an open access article distributed under the terms and conditions of the Creative Commons Attribution (CC BY) license (https:/ / creativecommons.org/licenses/by/ $4.0 /)$.
Abstract: Crack-free binary $\mathrm{SiO}_{x}: \mathrm{TiO}_{\mathrm{y}}$ composite films with the refractive index of $\sim 1.94$ at wavelength $632.8 \mathrm{~nm}$ were fabricated on soda-lime glass substrates, using the sol-gel method and dip-coating technique. With the use of transmission spectrophotometry and Tauc method, the energy of the optical band gap of $3.6 \mathrm{eV}$ and $4.0 \mathrm{eV}$ were determined for indirect and direct optical allowed transitions, respectively. Using the reflectance spectrophotometry method, optical homogeneity of $\mathrm{SiO}_{\mathrm{x}}: \mathrm{TiO}_{\mathrm{y}}$ composite films was confirmed. The complex refractive index determined by spectroscopic ellipsometry confirmed good transmission properties of the developed $\mathrm{SiO}_{\mathrm{x}}: \mathrm{TiO}_{\mathrm{y}}$ films in the Vis-NIR spectral range. The surface morphology of the $\mathrm{SiO}_{\mathrm{x}}: \mathrm{TiO}_{\mathrm{y}}$ films by atomic force microscopy (AFM) and scanning electron microscopy (SEM) methods demonstrated their high smoothness, with the root mean square roughness at the level of $\sim 0.15 \mathrm{~nm}$. Fourier-transform infrared (FTIR) spectroscopy and Raman spectroscopy were used to investigate the chemical properties of the $\mathrm{SiO}_{\mathrm{x}}: \mathrm{TiO}_{\mathrm{y}}$ material. The developed binary composite films $\mathrm{SiO}_{\mathrm{x}}: \mathrm{TiO}_{\mathrm{y}}$ demonstrate good waveguide properties, for which optical losses of $1.1 \mathrm{~dB} / \mathrm{cm}$ and $2.7 \mathrm{~dB} / \mathrm{cm}$ were determined, for fundamental $\mathrm{TM}_{0}$ and $\mathrm{TE}_{0}$ modes, respectively.

Keywords: silica-titania films; sol-gel; dip-coating technique; optical waveguide film; optical band gap; optical losses; planar waveguide

\section{Introduction}

Thin film technologies have played a key role in the development of microelectronics, and now they play the same role in optoelectronics. Attractive materials for the application in optoelectronics include transition metal oxides films (TMOs) $\left(\mathrm{TiO}_{2}, \mathrm{ZnO}, \mathrm{HfO}_{2}, \mathrm{ZrO}_{2}\right.$, $\mathrm{Ta}_{2} \mathrm{O}_{5}$ ) which, due to high optical energy band gaps, show good transmission properties in the Vis-NIR spectral range [1-8]. The $\mathrm{TiO}_{2}$ and $\mathrm{ZnO}$ films have sensor [9-12] and photocatalytic properties $[13,14]$. In the structures of photovoltaic cells, they are used as buffer films [15] or as acceptor films, blocking holes and effectively returning electrons to the anode $[16,17]$. TMO films with high refractive index and silica films $\left(\mathrm{SiO}_{2}\right)$ with low refractive index are used as components of multilayer photonic structures, such as dielectric mirrors $[18,19]$ or anti-reflective structures $[20,21]$ for applications in photovoltaics. TMOs are also used in integrated optics technologies [22-28]. TMO films can be produced using physical vapor deposition (PVD) methods, including e-beam evaporation [2,4], magnetron sputtering [7-9,13,23,29], pulse laser deposition PLD [30], or chemical methods, including 
chemical spray pyrolysis [12], atomic layer deposition (ALD) $[5,10,14,17]$ and the sol-gel method $[6,18,20,22,26,28]$. PVD methods require utilization of specialized technological instruments including vacuum systems. They are excellent for microelectronics applications; however, their yield in optoelectronics applications is low. Furthermore, the smoothness of TMO films fabricated using PVD methods is too low for application in integrated optics. A particularly attractive fabrication method of TMO films is the sol-gel method, whereof the most important advantages involve the ability to control the structure of material in a wide range as well as its high efficiency. The sol-gel method does not require complex technological installation, which is a significant advantage in terms of its implementation in small and medium-sized companies. The TMO films tend to crystallize, which is not an advantage in terms of optical applications as this leads to a dramatic increase in light scattering. For example: the crystallization of pure $\mathrm{TiO}_{2}$ started at $\sim 20{ }^{\circ} \mathrm{C}$ [31]. Additionally, the reduction in the annealing temperature of films fabricated with the sol-gel method below $430{ }^{\circ} \mathrm{C}$ does not remove all organic residues from them. The crystallization of TMO can be weakened by adding silicon dioxide $\left(\mathrm{SiO}_{2}\right)$ [31-33]. Thus, amorphous films can be obtained by the development of binary systems $\mathrm{MO}: \mathrm{SiO}_{2}$, where $\mathrm{MO}$ is a metal oxide. Consequently, by combining silica of low refractive index and MO of high refractive index, the possibility of shaping the refractive index in the range from $\sim 1.45$ to over 2 emerges. The greatest possibilities in terms of shaping the refractive index are provided by the use of titanium dioxide $\left(n_{\mathrm{TiO} 2} \sim 2.5\right)$ with silicon dioxide $\left(n_{\mathrm{SiO} 2} \sim 1.45\right)$. Sample applications of thin films fabricated using the sol-gel method are presented in Refs [34-37].

The subject of this work involves composite films $\mathrm{SiO}_{\mathrm{x}}: \mathrm{TiO}_{\mathrm{y}}$ of high refractive index, fabricated by the sol-gel method and dip-coating technique. Binary composite films $\mathrm{SiO}_{\mathrm{x}}: \mathrm{TiO}_{\mathrm{y}}$ with the proportion of components $\mathrm{SiO}_{\mathrm{x}}: \mathrm{TiO}_{\mathrm{y}}=1: 1$ have been investigated by us for many years [38-42]. The films developed by us have high refractive index $n \sim 1.8$, low optical losses, they remain stable over many years [40] and are characterized by high chemical and optical homogeneity [41]. These films are the material platform on which we develop the structures of integrated optics for applications in chemical/biochemical evanescent wave sensors [38,39]. On the basis of these waveguide films, grating couplers [38] and rib optical waveguides as well as directional couplers [39] have been developed. In this work, we present the results of our research on $\mathrm{SiO}_{\mathrm{x}}: \mathrm{TiO}_{\mathrm{y}}$ composite films with even higher refractive indexes ( $n \sim 1.94$ at wavelength $632.8 \mathrm{~nm}$ ), also fabricated by the sol-gel method and dipcoating technique. In the waveguide films of the refractive index of $n \sim 1.91$ at wavelength $632.8 \mathrm{~nm}$, we produced grating couplers whereof sensor properties were the subject of our earlier work [42]. The optical properties of the $\mathrm{SiO}_{\mathrm{x}}: \mathrm{TiO}_{\mathrm{y}}$ composite waveguide films presented here were investigated using spectrophotometric and ellipsometric methods. Surface morphology was investigated using the atomic force microscopy (AFM) and scanning electron microscopy (SEM), and chemical properties were tested using the methods of Fourier transform infrared (FTIR) and Raman spectroscopies. We also present the research results involving waveguide properties of the developed $\mathrm{SiO}_{\mathrm{x}}: \mathrm{TiO}_{\mathrm{y}}$ composite films.

The work is organized as follows. Section 2 describes the basics of the sol-gel method and the dip-coating technique, preparation method of the sol and the fabrication method of $\mathrm{SiO}_{\mathrm{x}}: \mathrm{TiO}_{\mathrm{y}}$ composite films, the applied materials used and technological procedures. Section 3 describes the applied measurement methods and apparatus used to characterize the presented composite films. The obtained results and their discussion are presented in Section 4, which also demonstrates that the developed $\mathrm{SiO}_{\mathrm{x}}: \mathrm{TiO}_{\mathrm{y}}$ composite films exhibit good waveguide properties.

\section{Technology}

\subsection{Fundamentals}

Binary composite films $\mathrm{SiO}_{\mathrm{x}}: \mathrm{TiO}_{\mathrm{y}}$ were fabricated using the sol-gel method and dipcoating technique. The fabrication processes of films in this way have multi-stage character, as illustrated in Figure 1. 


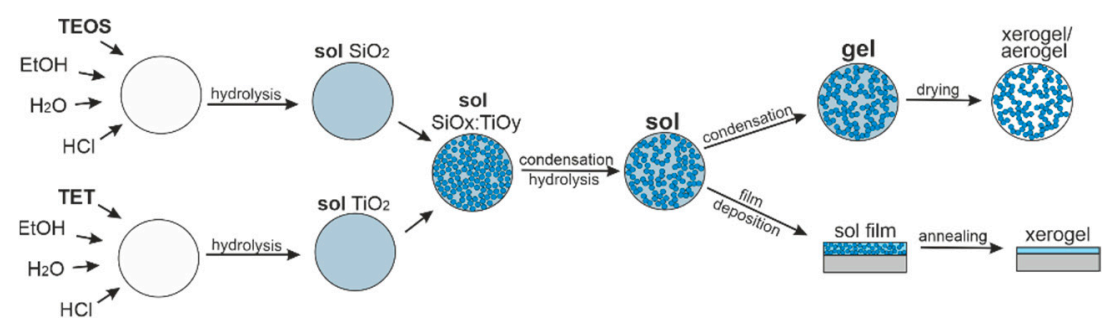

Figure 1. Scheme of sol-gel processes.

At the first stage, a sol is formed, which is the result of the hydrolysis of precursors. Almost simultaneously, the condensation process of hydrolysis products begins. In the hydrolysis reaction, the alkoxy groups are replaced with hydroxyl groups, according to reactions [43-45]:

$$
\mathrm{M}(\mathrm{OR})_{4}+\mathrm{H}_{2} \mathrm{O} \rightarrow \mathrm{HO}-\mathrm{M}(\mathrm{OR})_{3}+\mathrm{ROH}
$$

or

$$
\mathrm{M}(\mathrm{OR})_{4}+4 \mathrm{H}_{2} \mathrm{O} \rightarrow \mathrm{M}(\mathrm{OH})_{4}+4 \mathrm{ROH}
$$

where: $\mathrm{M}$-metal or non-metal atom (in our case $\mathrm{Si}$ or Ti), $\mathrm{R}$-alkyl group, $\mathrm{ROH}$-alcohol.

The hydrolysis process takes place partially or completely, depending on the amount of solvent. The condensation reaction, which takes place between two hydroxyl groups or one hydroxyl and alkoxyl group, leads to the formation of bonds between a metal or non-metal atom and oxygen [44,45]:

$$
(\mathrm{OR})_{3} \mathrm{M}-\mathrm{OH}+\mathrm{OH}-\mathrm{M}(\mathrm{OR})_{3} \rightarrow(\mathrm{OR})_{3} \mathrm{M}-\mathrm{O}-\mathrm{M}(\mathrm{OR})_{3}+\mathrm{H}_{2} \mathrm{O}
$$

or

$$
(\mathrm{OR})_{3} \mathrm{M}-\mathrm{OH}+\mathrm{OH}-\mathrm{M}(\mathrm{OR})_{3} \rightarrow(\mathrm{OR})_{3} \mathrm{M}-\mathrm{O}-\mathrm{M}(\mathrm{OR})_{3}+\mathrm{ROH}
$$

These reactions can be catalyzed by acids or bases.

There are three techniques used to production of thin layers in the sol-gel method [44]: spin-coating, dip-coating, and the meniscus coating technique. In this paper, the dip-coating technique was applied for the production of the $\mathrm{SiO}_{\mathrm{x}}: \mathrm{TiO}_{\mathrm{y}}$ waveguide layers on the glass substrate. This technique consists of several steps, which are presented in Figure 2. In the first stage, the glass substrate is immersed in the sol. After dipping the glass substrate in the sol, the glass substrate with a thin layer of sol is pulled up at a constant and controlled speed. After the removal of the glass substrate from the sol solution, a homogeneous film is formed on the substrate's surface. The sol films deposited on the substrate are then subject to drying and annealing. The thickness of the layer depends on the viscosity of the sol $\eta$, the liquid-vapor surface tension $\sigma$, and especially the withdrawal speed $v$ of the glass substate from the sol [46]. The general dependence of the film thickness $d$ on substrate withdrawal speed $v$ can be written in the following form [47]:

$$
d=A \xi v^{\alpha}
$$

where $\xi=1(\mathrm{~cm} / \mathrm{min})^{-\alpha}$ is the scaling factor. Depending on the properties of the sol and substrate withdrawal speed, its movement may cause a change in the curvature of sol meniscus at the boundary sol/substrate or not. When the sol exhibits the properties of a Newtonian fluid, then in the first case the slope $\alpha=1 / 2$ and the proportionality coefficient is $[44,46]$ :

$$
A=c_{1}\left(\frac{\eta}{\rho g}\right)^{1 / 2}
$$


where $c_{1} \approx 0.8, \rho$ is the density of sol, and $g$ is the gravity acceleration. Additionally, in the second case, slope $\alpha=2 / 3$ and the proportionality coefficient determined by Landau and Levich $[44,46]$ is:

$$
A=\frac{0.94 \eta^{2 / 3}}{\sigma^{1 / 3}(\rho g)^{1 / 2}}
$$

where: $\eta$ —urface stress along the phase border sol-air, $\sigma$-viscosity of sol.

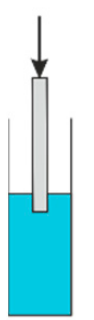

(a)

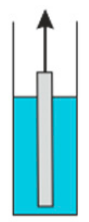

(b)

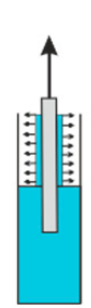

(c)

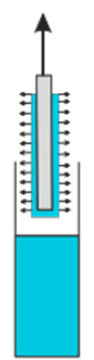

(d)

Figure 2. The stages of dip-coating technique. (a) Dipping the substrate in the sol, (b) beginning of the withdrawal, (c) withdrawal of the substrate from the sol, (d) pre-drying the layer.

In the above equations, the evaporation process of solvents was not taken into account. It should be emphasized that the thicknesses of the films in the drying and annealing processes undergo contraction and they are generally much smaller than the thicknesses of sol films immediately after their application [48]. In practice, the proportionality coefficient $A$ and slope $\alpha$ change with the aging time of the sol [47]. These coefficients are determined from the approximation of experimental dependencies $d=d(v)$ for the films after annealing, and they are used to design technological processes. In Section 4 we will demonstrate that the presented here composite films $\mathrm{SiO}_{\mathrm{x}}: \mathrm{TiO}_{\mathrm{y}}$ have good waveguide properties. From the optical point of view, after coating the substrate with a composite film of higher refractive index than that of the substrate, a three-film optical waveguide structure is formed on both sides of the substrate whereof the diagram is presented in Figure 3.

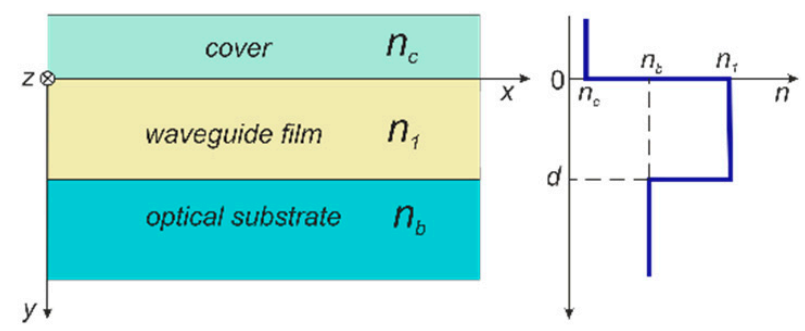

Figure 3. Scheme of the optical slab waveguide and its refractive index profile.

\subsection{Materials}

Tetraethyl orthosilicate (TEOS) and titania (IV) ethoxide (TET) were used as precursors of silica, and titania, respectively. Both precursors were purchased from Sigma-Aldrich (Steinheim, Germany) and used without any further purification. Anhydrous ethanol (EtOH; 99.8\%) and hydrochloric acid $(\mathrm{HCl} ; 36 \%)$ were supplied by Avantor Performance Materials (Gliwice, Poland). Soda-lime microscope slides (Menzel Gläser, Thermo Scientific, $n=1.513$ at $632.8 \mathrm{~nm}$ ) of dimension $76 \times 26 \times 1 \mathrm{~mm}^{3}$ were used as substrates. Deionized water was used directly from the deionizer (Polwater DL2-100S613TUV, Labopol Solutions\&Technologies, Kraków, Poland). The final $\mathrm{SiO}_{\mathrm{x}}: \mathrm{TiO}_{\mathrm{y}}$ synthesized sol was filtered through a $0.1 \mu \mathrm{m}$ PTFE syringe filter (Puradisc $25 \mathrm{TF}$, Whatman, Maidstone, UK). 


\subsection{Sol Preparation and Film Fabrication}

Silica-titania $\left(\mathrm{SiO}_{\mathrm{x}}: \mathrm{TiO}_{\mathrm{y}}\right)$ waveguide films were prepared via the sol-gel method and dip-coating technique, which was described in Section 2.1 and was presented in Figures 1 and 2. The preparation of gel solution was carried out in two stages. For the preparation of sols, we used ethanol as a homogenizing agent and hydrochloric acid $(36 \%)$ as the catalyst. In the first stage, two solutions of sols were separately prepared. For solution A, 0.09 mole of TEOS was mixed with 0.45 moles of ethanol, 0.18 moles of deionized water and 0.006 mole of $\mathrm{HCl}$. For solution B, 0.17 mole of TET was mixed with 1.4 moles of ethanol, 0.3 moles of deionized water and 0.08 moles of $\mathrm{HCl}$. Then, the solution $\mathrm{B}$ was added to the partially hydrolyzed solution $\mathrm{A}$, and the formation process of the gel solution was continued in an ultrasound field for $6 \mathrm{~h}$ at a temperature of $50^{\circ} \mathrm{C}$. The final molar ratio of (TET+TEOS): $\mathrm{EtOH}: \mathrm{H}_{2} \mathrm{O}: \mathrm{HCl}$ was 1:7.2:1.8:0.3, whereas the molar ratio of titania to silica was 1.94:1. Glass substrates were cleaned mechanically using a detergent solution, soaked in a solution of acetic acid, then isopropanol, and finally acetone. After each step (without the last one), the substrates were rinsed with distilled water. After filtering, the sol was stored at a temperature of $4{ }^{\circ} \mathrm{C}$. Composite $\mathrm{SiO}_{\mathrm{x}}: \mathrm{TiO}_{\mathrm{y}}$ films were deposited on the glass substrates dipped vertically in sol and withdrawn in a range of speed of $3.6-7.0 \mathrm{~cm} / \mathrm{min}$. After deposition by dip-coating technique, the films were annealed at $500{ }^{\circ} \mathrm{C}$ for $1 \mathrm{~h}$ under atmospheric pressure. Quality, and in particular uniformity, of films deposited using the dip-coating technique are sensitive to conditions in which those films are deposited. The issue of the effect the volume of sol and vessel as well as the atmosphere in which dip-coating processes are carried out are discussed in Ref. [49].

For FTIR measurements, a sample of the sol $(\sim 3 \mathrm{~mL})$ was dried and annealed at $500^{\circ} \mathrm{C}$ for $1 \mathrm{~h}$, yielding dry powder. For the purposes of measurements, using spectroscopic ellipsometry, a $\mathrm{SiO}_{\mathrm{x}}: \mathrm{TiO}_{\mathrm{y}}$ film was fabricated on the silicon substrate.

\section{Methods and Materials}

The produced films and the sol were subjected to physical and chemical characterization. The physical characterization consisted of examining the optical properties and surface morphology of the produced films, and the chemical characterization consisted of determining the chemical composition of the sol and that of the synthesized material in solid state. The surface morphology of the films was examined using the AFM and SEM measurement methods. The optical characterization was performed using spectrophotometric and ellipsometric methods. The chemical characterization was performed using the FTIR and Raman spectroscopies.

\subsection{Fourier Transform Infrared Spectroscopy}

The analysis of FTIR spectra recorded for the sol and for the powder obtained from the same sol allowed for the identification of chemical bonds in the materials of these samples. FTIR spectra were acquired using a Thermo Nicolet iS5 infrared spectrometer equipped with an ATR accessory. Spectra were performed at the resolution of $4 \mathrm{~cm}^{-1}$ in the range of $4000-400 \mathrm{~cm}^{-1}$, and 64 scans.

\subsection{Raman Spectroscopy}

The Raman spectrometer used in the study was a high resolution, confocal microspectrometer Almega XR of Thermo Electron Corp. The chosen excitation light wavelength was $532 \mathrm{~nm}$, objective magnification $100 \times$, and a pinhole aperture of $25 \mu \mathrm{m}$. Data were recorded in the spectral range from approx. $100 \mathrm{~cm}^{-1}$ up to $4000 \mathrm{~cm}^{-1}$ and with the spectral resolution of $2 \mathrm{~cm}^{-1}$.

\subsection{Spectrophotometry}

Transmittance and reflectance spectra of the $\mathrm{SiO}_{\mathrm{x}}: \mathrm{TiO}_{\mathrm{y}}$ thin films were used to determine of transmission properties, optical homogeneity and optical band gaps. The energies 
optical band gap of the $\mathrm{SiO}_{\mathrm{x}}: \mathrm{TiO}_{\mathrm{y}}$ films were determined by plotting Tauc's equations, which shows the dependence between absorption coefficient and photon energy:

$$
\alpha \cdot h v=B\left(h v-E_{g}\right)^{r}
$$

where: $B$ is a absorption constant, which does not depend on photon energy $h v, E_{\mathrm{g}}$ is the band gap of the material, $v$ is the frequency of the incident radiation, $h$ is the Planck's constant and power coefficient $r$ is the power coefficient, of which the value determines the optical transition. The coefficient $r$ takes the value of 2 for indirect allowed optical transitions and the value of $\frac{1}{2}$ for direct allowed optical transitions.

Based on the reflection spectra, the optical homogeneity of $\mathrm{SiO}_{\mathrm{x}}: \mathrm{TiO}_{\mathrm{y}}$ composite films was determined. For this purpose, the reflection spectra of the film and those of the substrate were compared. When the film is optically homogeneous, then in the spectral range away from the absorption edge, the interference minima of the reflection spectrum of the film lie on the reflection characteristics of the substrate [41,42].

Transmittance and reflectance studies of the $\mathrm{SiO}_{\mathrm{x}}: \mathrm{TiO}_{\mathrm{y}}$ waveguide films were carried out by using a UV-Vis AvaSpec-ULS2048LTEC Spectrophotometer (Avantes, Apeldoorn, The Netherlands). The AvaLight-DH-S-BAL (Avantes) was used as a light source. The spectra were recorded in the wavelength range of $200-1100 \mathrm{~nm}$, at room temperature.

\subsection{Ellipsometry}

The basic ellipsometry equation has the following form [50]:

$$
\rho=\frac{r_{p}}{r_{s}}=\tan \Psi \cdot \exp (i \Delta)
$$

where: $r_{p}$ and $r_{s}$ are complex reflection amplitude coefficients with parallel (subscript $p$ ) and perpendicular (subscript $s$ ) light polarization to the plane of incidence, respectively. The angles $\Psi$ and $\Delta$ are referred to as ellipsometric angels. The ellipsometric angles depend on the films, substate, cover parameters and wavelength $\lambda$.

At the stage of technological research, the refractive index and thickness of composite $\mathrm{SiO}_{\mathrm{x}}: \mathrm{TiO}_{\mathrm{y}}$ films were determined with the aid of a monochromatic ellipsometer SENTECH SE400 (Sentech, model 2003, $\lambda=632.8 \mathrm{~nm}$, Berlin, Germany). However, to determine the dispersion characteristics of the refractive index and extinction coefficient, the spectroscopic ellipsometer Woollam M2000 (J.A. Woollam Co. Inc., Lincoln, NE, USA) and CompleteEASE software were used.

In ellipsometric spectroscopic measurements, the key issue involves the correct choice of the dispersion model of dielectric functions. When testing various dispersion models, we selected the Tauc-Lorentz [51] dispersion model, defining our films in the best way, which describes well various amorphous materials, such as semiconductors [52], insulators [53], polymers [54], or even organic materials [55]. The Tauc-Lorentz model calculates the imaginary part of the dielectric function $\varepsilon^{(i)}$ by multiplying the Tauc joint density of states [56] and the $\varepsilon_{L}^{(i)}$ obtained from the Lorentz oscillator model. In our case, we used the two-oscillator Lorentz model, and hence the expression for the imaginary part of the dielectric function $\varepsilon^{(i)}$ has the form:

$$
\varepsilon^{(i)}=\left\{\begin{array}{ccc}
\sum_{j=1}^{2} \frac{A_{j} \cdot E_{j} \cdot C_{j} \cdot\left(E-E_{g}\right)^{2}}{\left(E^{2}-E_{j}^{2}\right)^{2}+C_{j}^{2} \cdot E^{2}} \times \frac{1}{E} & \text { for } & E>E_{g} \\
0 & \text { for } & E \leq E_{g}
\end{array}\right.
$$

The seven fitting parameters are $E_{g}, A_{1,2}, E_{1,2}$, and $C_{1,2}$, and all are in units of energy. The real part of the dielectric function $\varepsilon^{(r)}$ is derived by Kramers-Kronig integration:

$$
\varepsilon^{(r)}(E)=\varepsilon^{(r)}(\infty)+\sum_{j=1}^{2} \frac{2}{\pi} \cdot P_{c} \cdot \int_{E_{g}}^{\infty} \frac{\xi \cdot \varepsilon_{j}^{(i)}(\xi)}{\xi^{2}-E^{2}} d \xi
$$


where the $P_{c}$ stands for the Cauchy principal part of the integral and eight fitting parameters $\varepsilon^{(r)}(\infty)$ is the high frequency dielectric constant. Deriving these integral yields, the analytical expression of the real part of the dielectric function [51]. Refractive index and extinction coefficient have been calculated from the formulas:

$$
n(E)=\left[\frac{1}{2}\left(\varepsilon^{(r) 2}+\varepsilon^{(i) 2}\right)^{1 / 2}+\varepsilon^{(r)}\right]^{1 / 2}
$$

and

$$
\kappa(E)=\left[\frac{1}{2}\left(\varepsilon^{(r) 2}+\varepsilon^{(i) 2}\right)^{1 / 2}-\varepsilon^{(r)}\right]^{1 / 2}
$$

Knowing the refractive index $\mathrm{n}$ of the material of the fabricated $\mathrm{SiO}_{\mathrm{x}}: \mathrm{TiO}_{\mathrm{y}}$ composite films and the refractive indexes of the constituent materials $\left(n_{\mathrm{SiO} 2}=1.46, n_{\mathrm{TiO} 2}=2.52\right)$, the porosity $\mathrm{P}$ of the film material was estimated using the Lorentz-Lorenz formula

$$
P=\left[1-\frac{n^{2}-1}{n^{2}+2} \cdot \frac{n_{m}^{2}+2}{n_{m}^{2}-1}\right] \cdot 100 \%
$$

where $n$ is the refractive index of the films obtained from ellipsometric measurements $(\lambda=632.8 \mathrm{~nm})$, and $n_{m}$ is the refractive index of the two-component film $\mathrm{SiO}_{\mathrm{x}}: \mathrm{TiO}_{\mathrm{y}}$ calculated from the Lorentz-Lorenz formula based on the known composition of the film material:

$$
\frac{n_{m}^{2}-1}{n_{m}^{2}+2}=f_{1} \cdot \frac{n_{1}^{2}-1}{n_{1}^{2}+2}+f_{2} \cdot \frac{n_{2}^{2}-1}{n_{2}^{2}+2}
$$

We assumed here that $n_{1}{ }^{\circ} n_{\mathrm{SiO} x} \gg n_{\mathrm{SiO} 2}$ and $n_{2}{ }^{\circ} n_{\mathrm{TiO}}{ }{ } n_{\mathrm{TiO} 2}$. The $f_{1}$ and $f_{2}$ are the molar ratio of each component, which equals 0.34 and 0.66 , respectively.

\subsection{Surface Morphology}

The surface morphology of the silica-titania waveguide films was analyzed using a SEM and AFM. The SEM method was used to assess surface smoothness and to examine their cross-sections. The AFM method was used to record the images of film surfaces, and on their basis surface roughness of the films was determined (root mean square roughness).

The measurements of scanning electron microscopy were made with the SEM Supra 35 (Zeiss, Oberkochen, Germany) in the in-lens mode with accelerating voltages in the range from 2 to $10 \mathrm{kV}$. AFM measurements were carried out using AFM N_TEGRA (NTMDT, Moscow, Russia). Measurements were carried out at a resonance frequency equal to $136.281 \mathrm{kHz}$ in semi-contact mode with HA_NC (NT-MDT) silicon cantilever with nominal curvature radius of a tip $10 \mathrm{~nm}$. The average roughness measurements (RMS) were evaluated using NOVA 1.0.26.1644 (NT-MTD) software. The images were taken from an area of $1 \times 1 \mu \mathrm{m}^{2}$.

\section{Results and Discussion}

\subsection{FTIR}

The recorded FTIR spectra for the sol and for the powder obtained from it are presented in Figure 4a,b, respectively. The powder was made from the same sol after drying and annealing it at $500{ }^{\circ} \mathrm{C}$. The FTIR spectrum of the sol (Figure 4a) contains significantly more absorption bands than the FTIR spectrum of the $\mathrm{SiO}_{\mathrm{x}}: \mathrm{TiO}_{\mathrm{y}}$ powder. It complies with the expectations since the sol, also containing solvents, is a more complex chemical composition than the powder. The deep absorption bands in the transmittance of sol at the frequencies of $1044 \mathrm{~cm}^{-1}$ and $1086 \mathrm{~cm}^{-1}$, respectively, can come from the silica network and they can be attributed to asymmetric Si-O-Si stretching vibrations. At similar frequencies, there may also occur absorption bands connected with the presence of $\mathrm{C}-\mathrm{O}$ stretching vibrations, which in the case of sols are a natural consequence of the presence of organic compounds. The absorption band at $802 \mathrm{~cm}^{-1}$ may result from symmetrical Si-O-Si vibrations and 
symmetric vibrations of oxygen atoms parallel to the Si-O-Si bond [32,57]. The band at $430 \mathrm{~cm}^{-1}$ corresponds to Ti-O bonds in the $\mathrm{TiO}_{2}$ structure [32]. The wide absorption band at the frequency of $548 \mathrm{~cm}^{-1}$ may be related to the $\mathrm{Si}-\mathrm{C}$ stretching vibrations, which indicates the presence of chemical bonds between the organic and inorganic components of the sol [58]. The same frequency $\left(548 \mathrm{~cm}^{-1}\right)$ is assigned to the absorption band of the Ti-O-Ti bonds [57]. The absorption band at $952 \mathrm{~cm}^{-1}$ is assigned to both the stretching vibrations of $\mathrm{Si}-\mathrm{O}-\mathrm{Ti}$ and the vibrations from $\mathrm{SiO}-$ and $\mathrm{Si}-\mathrm{OH}$ groups [32,59]. From hydroxyl groups with hydrogen bonds also come the absorption bands at the frequencies of $3299 \mathrm{~cm}^{-1}$ (stretching vibrations), $1656 \mathrm{~cm}^{-1}$ (bending vibrations of water), $1380 \mathrm{~cm}^{-1}$ (deformation vibrations) and $879 \mathrm{~cm}^{-1}$ (vibrations of the -OH groups with methyl groups) [45,60]. The remaining absorption bands at the frequencies of $2972 \mathrm{~cm}^{-1}$ and $2880 \mathrm{~cm}^{-1}$ are attributed to the aliphatic $\mathrm{C}-\mathrm{H}$ stretching vibrations.

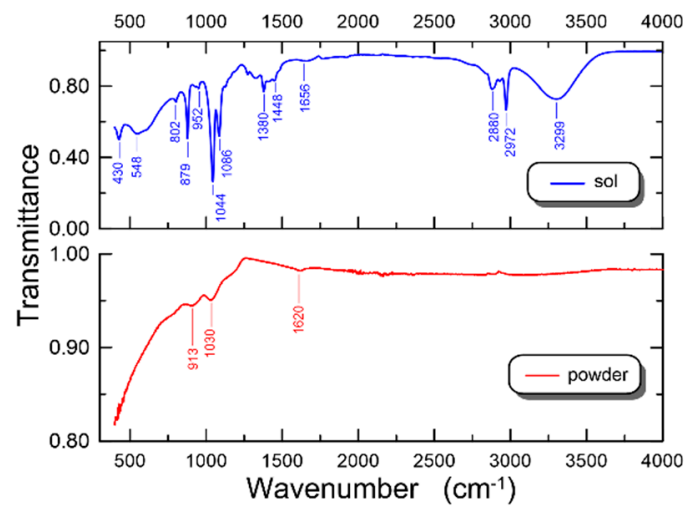

(b)

Figure 4. FTIR spectrum of the sol (a) and powder of silica-titania (b).

In the FTIR spectrum of the $\mathrm{SiO}_{\mathrm{x}}: \mathrm{TiO}_{\mathrm{y}}$ powder (Figure $4 \mathrm{~b}$ ) there are no absorption bands resulting from the vibrations of hydroxyl groups $\left(3299 \mathrm{~cm}^{-1}, 1380 \mathrm{~cm}^{-1}\right)$. Additionally, we can observe a weak absorption band at the frequency of $1620 \mathrm{~cm}^{-1}$, which probably comes from the residual vibrations of the -OH groups, which is the result of water adsorption by $\mathrm{SiO}_{2}$, as silica has a high ability to adsorb it [60]. After annealing of the $\mathrm{SiO}_{\mathrm{x}}: \mathrm{TiO}_{\mathrm{y}}$ powder at the temperature above $400{ }^{\circ} \mathrm{C}$, no absorption bands coming from organic groups were recorded. In the frequency range from $400 \mathrm{~cm}^{-1}$ to about $1200 \mathrm{~cm}^{-1}$, we observe vibration bands of the $\mathrm{Si}-\mathrm{O}$ and Ti-O bonds. There is a characteristic absorption band coming from the asymmetric stretching vibrations of Si-O-Si $\left(1030 \mathrm{~cm}^{-1}\right)$, which in the spectrum of the sol could be obscured by the stretching vibrations band of $\mathrm{C}-\mathrm{O}$. The presence of the absorption band at the frequency of $913 \mathrm{~cm}^{-1}$ in the solid phase, resulting from the vibrations of the Si-O-Ti cross-bonds, is interpreted as evidence confirming the presence of the amorphous phase [32].

\subsection{Raman Spectroscopy}

Baseline correction for all data was conducted prior to the analyzing procedure and each spectrum was normalized. Figure 5 shows the Raman spectra of a raw xerogel sample (obtained at room temperature) and sample annealed at $500{ }^{\circ} \mathrm{C}$ for $60 \mathrm{~min}$. For the purpose of accurate analysis in all the spectra obtained, the spectral range was divided into two regions. As we can see, the Raman spectrum for the raw sample contains peaks that are characteristic of both the post-process organic phase and the titanium oxide. The former phase is manifested by the presence of bands in the high wavenumber range, where the stretching transition of water is observed in the range $3000-3600 \mathrm{~cm}^{-1}$ which comes from both symmetrical and asymmetrical stretching vibrations of the -OH group [61]. Moreover, we see a bending overtone of water centered around $1640 \mathrm{~cm}^{-1}$. The weak peak around $2900 \mathrm{~cm}^{-1}$ comes from the $\mathrm{C}-\mathrm{H}$ stretching vibrations. This peak is characteristic for ethanol. In the low wavenumbers range, we observed broad bands with the wide line width located at $930 \mathrm{~cm}^{-1}, 830 \mathrm{~cm}^{-1}, 620 \mathrm{~cm}^{-1}, 506 \mathrm{~cm}^{-1}, 400 \mathrm{~cm}^{-1,} 255 \mathrm{~cm}^{-1}$ and $148 \mathrm{~cm}^{-1}$. The peaks 
are observed in the vicinity of the active modes of $\mathrm{TiO}_{2}$ (Table 1 in Ref. [62]). However, the weak Raman signal corresponds to the low degree of crystallinity indicating the dominance of amorphous phase. The spectrum of the raw sample also shows a weak band around $1075 \mathrm{~cm}^{-1}$. This band can be derived from asymmetric and symmetric stretching vibrations of the silica network [63].

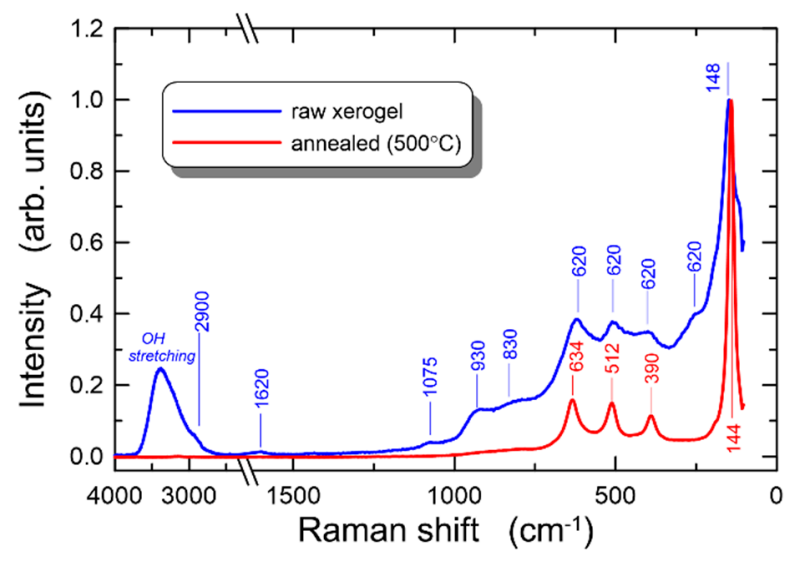

Figure 5. Comparison of Raman spectra for raw xerogel and xerogel annealed at $500{ }^{\circ} \mathrm{C}$ for $60 \mathrm{~min}$.

Table 1. Parameters of the Tauc-Lorentz model fit to experimental data.

\begin{tabular}{cccccccc}
\hline $\begin{array}{c}E_{\boldsymbol{g} 1} \\
(\mathbf{e V})\end{array}$ & $\begin{array}{c}A_{\mathbf{1}} \\
(\mathbf{e V})\end{array}$ & $\begin{array}{c}E_{\mathbf{0 1}} \\
\mathbf{( e V )}\end{array}$ & $\begin{array}{c}\boldsymbol{B}_{\mathbf{1}} \\
\mathbf{( e V )}\end{array}$ & $\begin{array}{c}E_{g_{2}} \\
(\mathbf{e V})\end{array}$ & $\begin{array}{c}A_{\mathbf{2}} \\
(\mathbf{e V})\end{array}$ & $\begin{array}{c}E_{\mathbf{0 2}} \\
(\mathbf{e V})\end{array}$ & $\begin{array}{c}\boldsymbol{B}_{\mathbf{2}} \\
(\mathbf{e V})\end{array}$ \\
\hline $3.323 \pm 0.005$ & $93 \pm 4$ & $6.2 \pm 0.3$ & $14 \pm 1$ & $\begin{array}{c}33.600 \pm \\
0.006\end{array}$ & $93.5 \pm 2.3$ & $4.28 \pm 0.01$ & $1.50 \pm 0.02$ \\
\hline
\end{tabular}

This band, however, is not noticeable for the sample annealed at $500{ }^{\circ} \mathrm{C}$. In general, silica gives a weak Raman signal, and when anatase bands clearly develop in the spectrum (at high temperature), the silica signal may be weakened and covered with stronger titanium oxide lines. In a Raman spectrum of a sample annealed at $500{ }^{\circ} \mathrm{C}$, the peaks from the organic phase disappeared. Moreover, we can see that the peaks located at $634 \mathrm{~cm}^{-1}, 512 \mathrm{~cm}^{-1}, 390 \mathrm{~cm}^{-1}$ and $144 \mathrm{~cm}^{-1}$ are well developed. The broad peaks observed previously become sharper and more intense, signifying an increase in crystalline phase content in the sample. The observed peaks are consistent with the presence of the anatase phase. Especially, the most intense band centered at $144 \mathrm{~cm}^{-1}$ is a particularly sensitive detector of even very small amounts of crystalline $\mathrm{TiO}_{2}$ in anatase form. In general, anatase has the space group D4h (I41/amd). Based on the factor group analysis, and assuming site symmetries for $\mathrm{Ti}$ and $\mathrm{O}$ atoms in the unit cell, there are six Raman active modes for anatase, assigned as follows: A1g $\left(512 \mathrm{~cm}^{-1}\right)+\mathrm{B} 1 \mathrm{~g}\left(399 \mathrm{~cm}^{-1}\right)+\mathrm{B} 1 \mathrm{~g}\left(518 \mathrm{~cm}^{-1}\right)+\mathrm{Eg}$ $\left(144 \mathrm{~cm}^{-1}\right)+\mathrm{Eg}\left(198 \mathrm{~cm}^{-1}\right)+\mathrm{Eg}\left(639 \mathrm{~cm}^{-1}\right)$. The weak band observed in spectrum at about $830 \mathrm{~cm}^{-1}$ was assigned as the first overtone of the B1g mode of anatase.

\subsection{Effect of Withdrawal Speed}

Exemplary dependences of the final thicknesses $\mathrm{d}$ and refractive indexes $\mathrm{n}$ of the composite films $\mathrm{SiO}_{\mathrm{x}}: \mathrm{TiO}_{\mathrm{y}}$ on the withdrawal speed $\mathrm{v}$ are presented in Figure 6. Full squares are used to indicate the experimental dependence $d=d(v)$, and empty squares are used to present the experimental dependence $n=n(v)$. The film thicknesses increase with the increasing speed $v$, while the refractive indices remain constant. By changing the speed $v$ from 3.9 to $6.5 \mathrm{~cm} / \mathrm{min}$, we obtained $\mathrm{SiO}_{\mathrm{x}}: \mathrm{TiO}_{\mathrm{y}}$ films with thicknesses ranging from 130 to $170 \mathrm{~nm}$. The experimental dependence $d=d(v)$ was approximated by the function (5), where $a=0.522 \pm 0.002$ and $A=(63.70 \pm 0.15) \mathrm{nm}$. Additionally, the experimental dependence of the refractive index $n$ on the withdrawal speed was approximated by the 
linear function $n=n_{0}+g \times v$, obtaining $n_{0}=1.9372 \pm 0.0012$ and $g=(-0.0012 \pm 0.0002)$ $\mathrm{min} / \mathrm{cm}$. Thus, we can observe that the refractive index of the fabricated films depends to a very small extent on the withdrawal speed $v$. In both cases, the experimental points are close to the approximating lines.

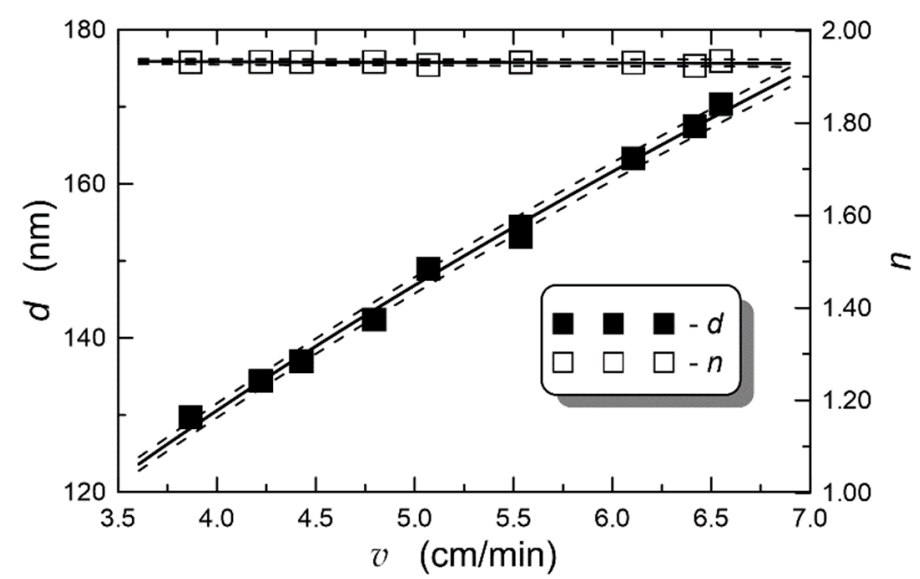

Figure 6. Influence of substrate withdrawal speed from sol on final thickness and refractive index of the composite $\mathrm{SiO}_{\mathrm{x}}$ : $\mathrm{TiO}_{\mathrm{y}}$ films. Aging time of sol equal 27 days, annealing at $500{ }^{\circ} \mathrm{C}$ for $1 \mathrm{~h} . \lambda=632.8 \mathrm{~nm}$.

\subsection{Effect of Sol Aging}

The hydrolysis and condensation reactions are still taking place in the sol, even when it is stored at lower temperature. Thus, the sol thickens over time and its viscosity increases. This results in increasingly thicker films, produced at the same withdrawal speed $v$. This effect is illustrated in Figure 7, which shows, respectively, the dependence of the final film thickness and its refractive index on the storage time of the sol, for the withdrawal speed $v=5.0 \mathrm{~cm} / \mathrm{min}$. Everytime sols after usage were stored at a temperature of $4^{\circ} \mathrm{C}$. The points marked with diamonds and the error bars were determined from the approximation of the experimental characteristics $d=d(v)$ and $n=n(v)$ (Figure 4). Here, maximum uncertainties are plotted with error bars. It can be seen that the final film thickness increases linearly with the storage time of the sol, and the refractive index remains constant at $~ 1.94$. This means that the produced sol can be used for a longer period of time, yet it requires that we know the influence of its storage time on its viscosity and, consequently, on the thickness of the produced films at specific withdrawal speeds. The knowledge of such dependencies as shown in Figure 7 is necessary from the viewpoint of the designing processes for the fabrication of waveguide films.

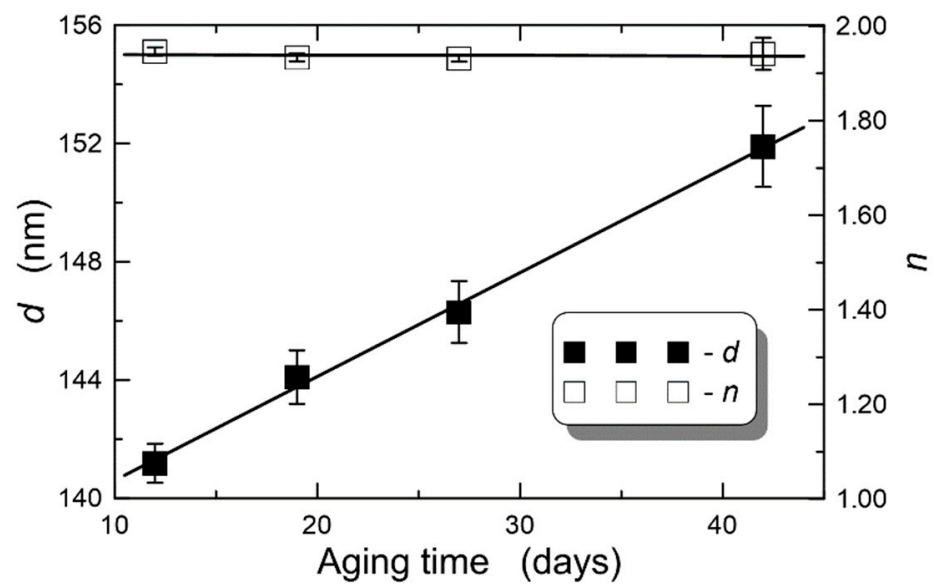

Figure 7. Influence of sol aging time on film thickness and refractive index for withdrawal speed of substrates from sol $v=5.0 \mathrm{~cm} / \mathrm{min} . \lambda=632.8 \mathrm{~nm}$. 


\subsection{Surface Morphology}

Figure 8a presents an exemplary, AFM image of the surface of a $\mathrm{SiO}_{\mathrm{x}}: \mathrm{TiO}_{\mathrm{y}}$ composite film deposited on a soda-lime glass substrate, and after heat treatment for $1 \mathrm{~h}$ at $500{ }^{\circ} \mathrm{C}$. As we can easily observe, the film is very smooth, and the difference between the lowest and the highest point on the tested surface $1.0 \times 1.0 \mu \mathrm{m}^{2}$ is $1.19 \mathrm{~nm}$, while the root mean square surface roughness derived from this image is $r m s=0.15 \mathrm{~nm}$. Section 4.6 shows waveguide properties of the $\mathrm{SiO}_{\mathrm{x}}: \mathrm{TiO}_{\mathrm{y}}$ composite films presented here. The roughness of the interphases of the waveguide film is the source of scattering losses. These losses are proportional to the squared $r m s$, to $\left(n_{1}^{2}-n_{c}^{2}\right)^{2}$ and to the power density on the boundary surfaces of the waveguide film [64]. In single-mode waveguide films of high refractive index, there are high power densities on the boundary surfaces, and hence the acquisition of low scattering losses is conditioned by their low roughness. In binary composite waveguide films, $\mathrm{SiO}_{\mathrm{x}}$ : $\mathrm{TiO}_{\mathrm{y}}$ containing more than $20 \%$ of titanium oxide, it tends to crystallize and form a separated crystal phase, which negatively affects the smoothness of the film surface. In such a case, an increase in scattering losses on the surface of the waveguide film will be observed, and strong scattering in the volume of the film material will occur. We have to face a very difficult technological challenge to prevent this effect. High smoothness of the surface can be interpreted as a confirmation of the amorphous nature of the $\mathrm{SiO}_{\mathrm{x}}: \mathrm{TiO}_{\mathrm{y}}$ composite waveguide films presented here.

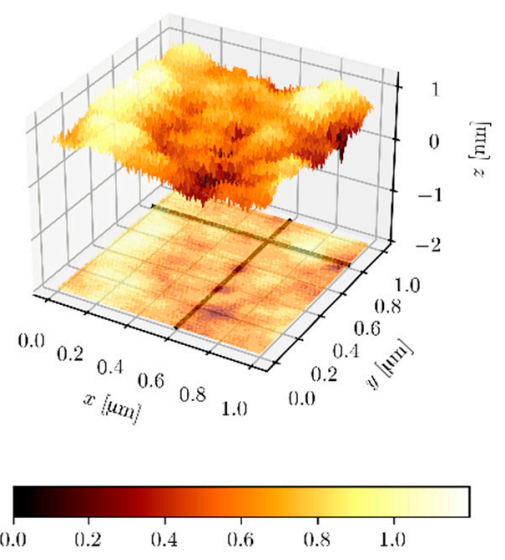

(a)

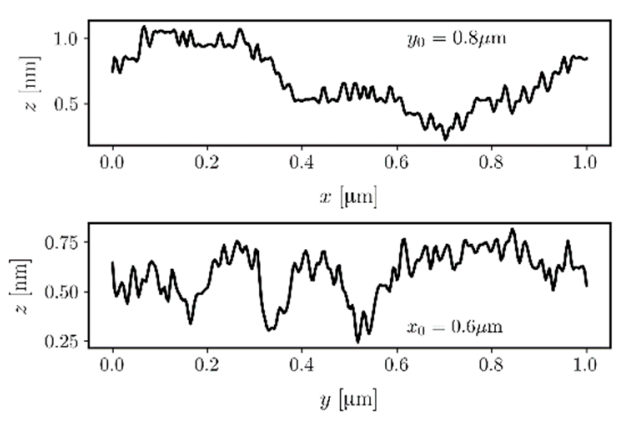

(b)

Figure 8. (a) AFM topographical image of an $\mathrm{SiO}_{\mathrm{x}}$ : $\mathrm{TiO}_{\mathrm{y}}$ thin film deposited on a soda-lime glass substrate, obtained for the area of size $1.0 \times 1.0 \mu \mathrm{m}^{2}$. (b) Surface profiles in two cross-sections.

The SEM image of the upper surface of the waveguide film is shown in Figure 9a, while the cross-section of the structure is shown in Figure 9b. In Figure 9a, a smooth, continuous surface of the composite waveguide film is observed, with no cracks or visible defects. Figure $9 \mathrm{~b}$, which shows a cross-section of the film applied onto soda-lime glass substrate, indicates a uniform film thickness $(d=159.2 \mathrm{~nm})$. SEM images confirm high homogeneity of the $\mathrm{SiO}_{x}: \mathrm{TiO}_{y}$ films and high smoothness of their surfaces. 


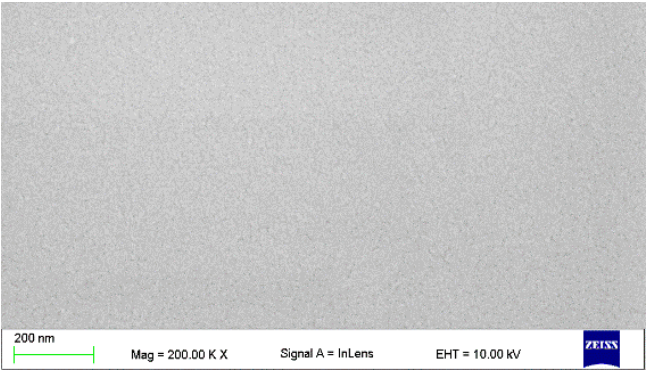

(a)

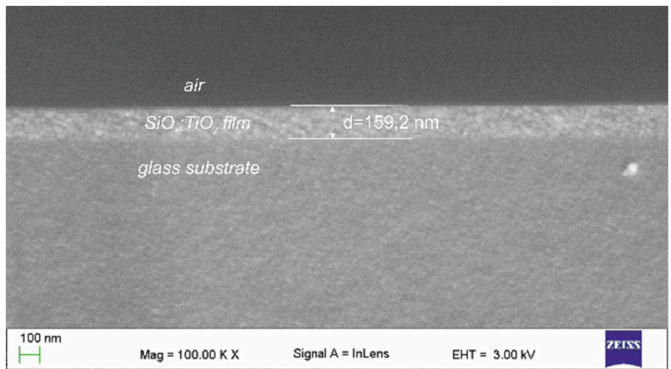

(b)

Figure 9. SEM images of top (a) and cross section (b) of the slab waveguide structure.

\subsection{Optical Properties}

The ellipsometric spectroscopic studies were performed for the $\mathrm{SiO}_{\mathrm{x}}: \mathrm{TiO}_{\mathrm{y}}$ composite film fabricated on a silica substrate whose optical dispersion properties are very well known [65].

The registered dispersion characteristics of the ellipsometric angles $\Psi(\lambda)$ and $\Delta(\lambda)$ at the illumination angle of the sample $\theta=70^{\circ}$ were plotted with solid lines in Figure 10 . The modeled dispersion characteristics were plotted with dashed lines, calculated using the Tauc-Lorentz formula presented in Section 3.4, in which two oscillators were taken into account. For the applied model, eight parameters were fitted, whereof the calculated values are summarized in Table 1. As we can observe in Figure 10, a perfect fit of the modeled dispersion characteristics of the ellipsometric angles to the experimental characteristics was obtained. The calculations were used to determine the thickness of the $\mathrm{SiO}_{\mathrm{x}}: \mathrm{TiO}_{\mathrm{y}}$ composite film $d=139.2 \mathrm{~nm}$. The refractive index $n(l)$ and the extinction coefficient $k$ (l), determined, respectively, from the formulas (12) and (13), are shown in Figure 11 $(E=1240 / l)$. As we can observe, in the spectral range above $300 \mathrm{~nm}$, normal dispersion of the refractive index occurs, while below the wavelength of $300 \mathrm{~nm}$, anomalous dispersion is observed, which is related to the presence of an absorption band in this spectral range.

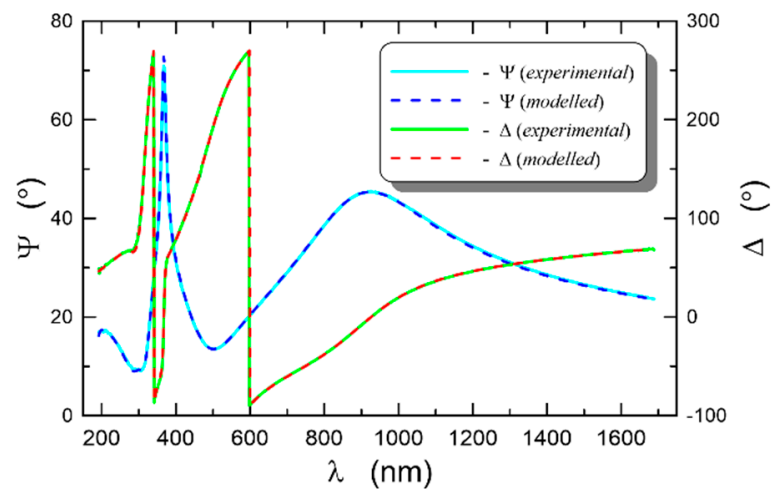

Figure 10. Dispersion characteristics of the ellipsometric angles for composite a $\mathrm{SiO}_{\mathrm{x}}: \mathrm{TiO}_{\mathrm{y}}$ film on a silicon substrate. The illumination angle equals $70^{\circ}$. 


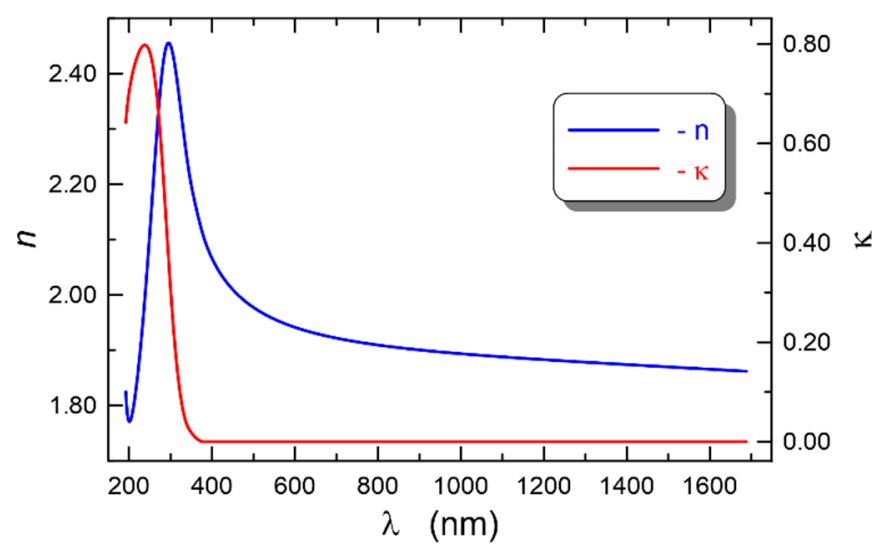

Figure 11. Dispersion characteristics of the refractive index and extinction coefficient for a composite $\mathrm{SiO}_{\mathrm{x}}: \mathrm{TiO}_{\mathrm{y}}$ film.

Optical absorption in composite $\mathrm{SiO}_{\mathrm{x}}: \mathrm{TiO}_{\mathrm{y}}$ films was studied by UV-Vis spectroscopy in the spectral range of $200-1100 \mathrm{~nm}$. The plots of transmittance of the selected composite film $\mathrm{SiO}_{\mathrm{x}}: \mathrm{TiO}_{\mathrm{y}}$ of different thicknesses are shown in Figure 12. In this Figure is shown the transmission characteristic of the soda-lime glass substrate (depicted as a grey line). The spectra of $\mathrm{SiO}_{\mathrm{x}}: \mathrm{TiO}_{\mathrm{y}}$ films show a high transmission above $400 \mathrm{~nm}$ wavelength and a strong absorption edge (observed as a decrease in transmittance) below $400 \mathrm{~nm}$.

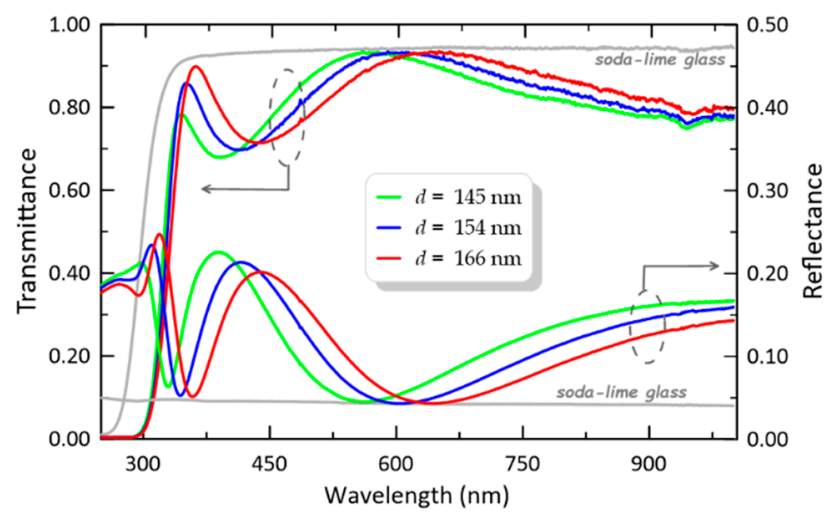

Figure 12. Transmittance and reflectance spectra of the $\mathrm{SiO}_{\mathrm{x}}$ : $\mathrm{TiO}_{\mathrm{y}}$ films for selected thickness.

The line of transmittance of the soda-lime slide is the upper envelope of transmittance of composite $\mathrm{SiO}_{\mathrm{x}}: \mathrm{TiO}_{\mathrm{y}}$ films which indicate that those films are uniform. Additionally, the uniformity of $\mathrm{SiO}_{\mathrm{x}}: \mathrm{TiO}_{\mathrm{y}}$ films is indicated by the small refractive index variation, which was mentioned in Section 3.2.

The plots of reflectance characteristics of selected composite $\mathrm{SiO}_{\mathrm{x}}: \mathrm{TiO}_{\mathrm{y}}$ films are also shown in Figure 12. The solid grey line is corresponding to the reflectance of the soda-lime glass substrate. As can be seen, that interference minima lie on the reflectance characteristic of the soda-lime glass substrate for the wavelengths above $400 \mathrm{~nm}$, which clearly shows the homogeneity of the layers and the lack of absorption.

Based on the UV-Vis transmittance spectra, the optical band gap was determined using Tauc's Equation (8). Figure 13 shows the plot of $(\alpha \cdot h v)^{2}$ and $(\alpha \cdot h v)^{1 / 2}$ on the energy photon for two selected silica-titania layers with different thicknesses, coated on a soda-lime glass substrate. The optical bandgap was calculated by extrapolating the linear part of the curve as a function of $(h v)$ curve to $\alpha=0$. For these layers, the determined values of the indirect energy bandgaps were $3.589 \mathrm{eV}$ and $3.543 \mathrm{eV}$ for the thicknesses of 145 and $166 \mathrm{~nm}$, respectively (Figure 13a), whereas the direct energy bandgaps were 4.012 $\mathrm{eV}$ and $3.985 \mathrm{eV}$ for 145 and $166 \mathrm{~nm}$, respectively (Figure 13b). The high values of energy band gaps proved the amorphous structure of the presented $\mathrm{SiO}_{\mathrm{x}}: \mathrm{TiO}_{\mathrm{y}}$ waveguide layers. 


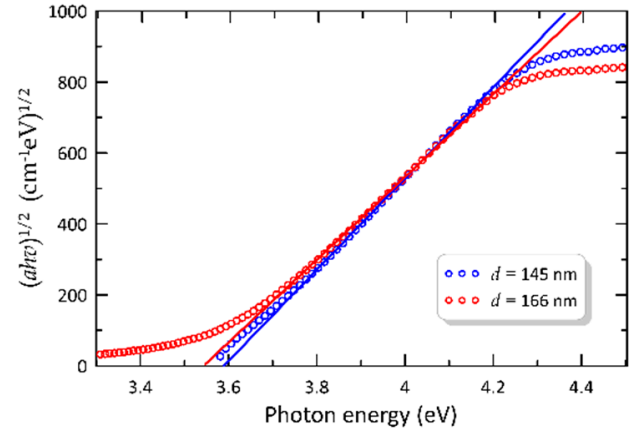

(a)

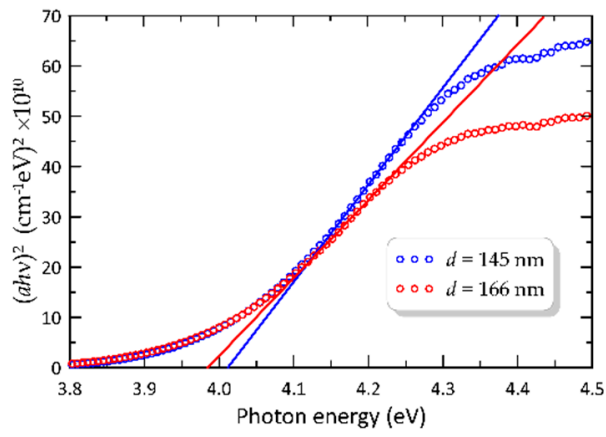

(b)

Figure 13. Tauc plot of $(\alpha \cdot h v)^{1 / 2}$ and $(\alpha \cdot h v)^{2}$ as a function of $(h v)$ for indirect (a) and direct (b) optical transitions, respectively.

Table 2 shows the values of energy bandgaps for the silica-titania layers obtained at various time intervals. As can be seen, the value of the energy bandgap practically does not depend on the aging time of the sol.

Table 2. Influence of sol aging time on optical band gaps.

\begin{tabular}{cccc}
\hline $\begin{array}{c}\text { Aging Time } \\
\text { (Day) }\end{array}$ & $\begin{array}{c}\boldsymbol{d} \\
(\mathbf{n m})\end{array}$ & $\begin{array}{c}E_{g} \text { Indirect } \\
\mathbf{( e V )}\end{array}$ & $\begin{array}{c}E_{g} \text { Direct } \\
(\mathbf{e V})\end{array}$ \\
\hline 19 & 165.13 & 3.580 & 3.973 \\
27 & 148.89 & 3.618 & 4.021 \\
& 170.36 & 3.591 & 4.006 \\
42 & 160.63 & 3.589 & 4.012 \\
& 177.42 & 3.590 & 3.983 \\
\hline
\end{tabular}

Taking into account the refractive index of silica $n_{\mathrm{SiO} 2}=1.46$ and titania $n_{\mathrm{TiO} 2}=2.52$, using formula (15), we obtained $n_{m}=2.05$, and then using the measured values of the refractive index $n$ of the produced composite $\mathrm{SiO}_{\mathrm{x}}: \mathrm{TiO}_{\mathrm{y}}$ films, their volume percentage porosity $P$ was determined using the Lorentz-Lorenz formula (Equation (14)). We found that the porosity of the composite $\mathrm{SiO}_{\mathrm{x}}: \mathrm{TiO}_{\mathrm{y}}$ fabricated by us is $\mathrm{P} \approx 7 \%$ for all the prepared samples.

\subsection{Waveguide Properties}

The $\mathrm{SiO}_{x}: \mathrm{TiO}_{\mathrm{y}}$ composite films presented here have good waveguide properties. Figure 14 shows the images of an excited waveguide into which light was launched with the use of a prism coupler and by means of the optical tunneling effect. We can observe streaks of scattered light whereof intensity decreases along the path of propagation. It can be seen from the comparison of the images for $\mathrm{TM}_{0}$ and $\mathrm{TE}_{0}$ modes that stronger optical losses take place for TE polarization. From the light intensity distribution along the streak, the optical loss factor $m$ can be determined. It is assumed in this procedure that: (i) the waveguide is homogeneous in the direction of light propagation, (ii) at each point $x$ of the scattered light streak, its intensity is proportional to the optical power that is guided in the waveguide film at this point. With such assumptions, it can be written that the light intensity distribution along the streak is determined by the relationship: $P(x)=$ $P(x=0) \cdot \exp (-m \times x)$. For the waveguide shown in Figure $14\left(n_{1}=1.9383, d=145.7 \mathrm{~nm}\right)$, the determined optical losses are, respectively, $a_{T M}=4.343 \mathrm{~m}=1.1 \mathrm{~dB} / \mathrm{cm}$ for mode $\mathrm{TM}_{0}$ and $a_{T E}=4.343 \mathrm{~m}=2.7 \mathrm{~dB} / \mathrm{cm}$ for mode $\mathrm{TE}_{0}($ at $\lambda=676.7 \mathrm{~nm})$. These losses are several times higher than those for the previously reported $\mathrm{SiO}_{\mathrm{x}}: \mathrm{TiO}_{\mathrm{y}}$ waveguide films with lower refractive indices [40,42]. This result does not come as a surprise to us, because in the composite $\mathrm{SiO}_{\mathrm{x}}: \mathrm{TiO}_{\mathrm{y}}$ films presented here we have a much higher content of titanium. Similar optical losses were obtained by Heideman et al. [25] for $\mathrm{ZnO}$ waveguide films with refractive indices of 1.93-1.96 (at $\lambda=632.8 \mathrm{~nm}$ ), which were produced by the RF 
magnetron sputtering method. Ref. [28] reported erbium-doped $\mathrm{ZrO}_{2}$ waveguide films with refractive indices of 1.83-1.92 and optical losses exceeding $1 \mathrm{~dB} / \mathrm{cm}$. In the waveguide film $\mathrm{TiO}_{2}$ of refractive index $n \sim 2$ and thickness $d=336 \mathrm{~nm}$, Tauam et al. [22] measured the optical losses for the fundamental mode $\mathrm{TM}_{0}$ amounting to $0.8 \mathrm{~dB} / \mathrm{cm}$. However, it should be emphasized that it was a two-mode waveguide, and the measurement was made only for the fundamental mode. In the measurements of our films by spectroscopic ellipsometry and spectrophotometric measurements, we did not report the presence of absorption bands in the Vis-NIR spectral ranges above the wavelength of $400 \mathrm{~nm}$. This means that the optical losses can only be affected by scattering on the boundary surfaces of the waveguide film and on the inhomogeneities of the material in its volume. The AFM and SEM tests demonstrated high surface smoothness of the waveguide film, and hence it can be concluded that its influence on optical losses is negligible. Thus, the main source of losses may be attributed to the scattering on the surface waveguide film/substrate and to the scattering in the volume of the film.

Figure 15 presents mode characteristics of a slab waveguide with the refractive indices of $n_{b}-n_{1}-n_{c}=1.51-1.94-1.00$, calculated for the wavelength $\lambda=677 \mathrm{~nm}$. The cut-off thicknesses are $66.75 \mathrm{~nm}$ and $134.25 \mathrm{~nm}$ for the base modes $\mathrm{TE}_{0}$ and $\mathrm{TM}_{0}$, and $344.25 \mathrm{~nm}$ and $456.00 \mathrm{~nm}$ for the first order modes $\mathrm{TE}_{1}$ and $\mathrm{TM}_{1}$, respectively. Figure 16 presents the normalized power density distributions of the fundamental modes $\mathrm{TE}_{0}$ and $\mathrm{TM}_{0}$ calculated with the use of the transfer matrix method [38]. The area of the waveguide film is marked in gray. As we can observe, power density of the fundamental mode $\mathrm{TE}_{0}$ is greater than that of mode $\mathrm{TM}_{0}$ both on boundary surfaces of the waveguide film and in its volume. Hence, for the $\mathrm{TE}_{0}$ mode, light scattering both on boundary surfaces of the waveguide film and in its volume are greater than that for the $\mathrm{TM}_{0}$ mode. Consequently, as can be seen from Figure 14, optical losses for the $\mathrm{TE}_{0}$ mode are higher than those for the $\mathrm{TM}_{0}$ mode.

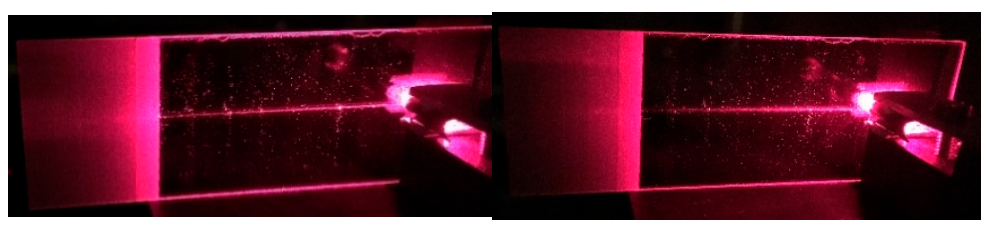

(a)

(b)

Figure 14. Images of the excited slab waveguides. (a) $\mathrm{TM}_{0}$ mode, (b) $\mathrm{TE}_{0}$ mode, $\lambda=676.7 \mathrm{~nm}$.

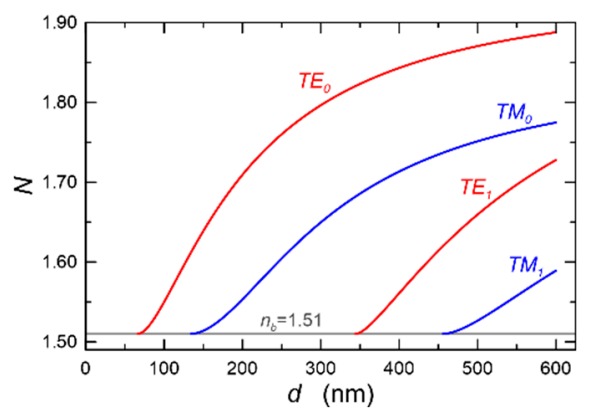

Figure 15. Modal characteristics of the slab waveguide. $n_{b}-n_{1}-n_{c}=1.51-1.94-1.00, \lambda=677 \mathrm{~nm}$. 


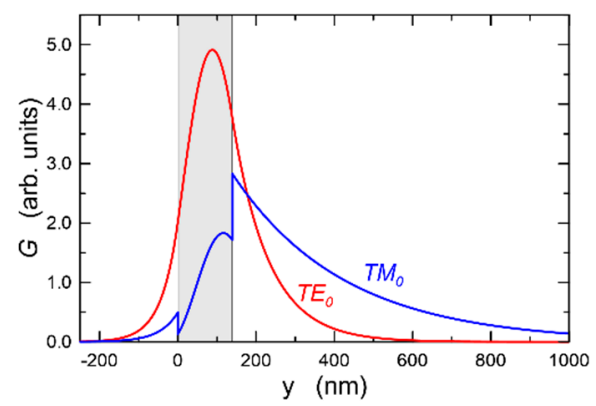

Figure 16. Distribution of the power density in the slab waveguide $n_{b}-n_{1}-n_{c}=1.51-1.94-1.00, d=146$ $\mathrm{nm}, \lambda=677 \mathrm{~nm}$.

After the application of a sol film on the soda-lime substrate, a grating coupler of period of $\Lambda=417 \mathrm{~nm}$ was fabricated in it using the nanoimprint method, and then the structure was subjected to annealing at the temperature of $500{ }^{\circ} \mathrm{C}$ for $60 \mathrm{~min}$. In this way, a waveguide structure with a grating coupler was obtained, which allows for efficient light coupling into the waveguide film. The sol film was applied at the same withdrawal speed as for the structure shown in Figure 14. As demonstrated in Refs. [38,42], planar waveguide structures with grating couplers are highly sensitive sensor structures. Figure 17 shows a planar waveguide structure, excited with the use of the fabricated grating coupler. We can observe a streak of scattered light along the waveguide and a very strong optical signal that reached the matte area on the applied glass substrate. Figure 18 shows the excitation characteristics of a planar waveguide structure with a grating coupler, recorded in the measurement system described in Ref. [42]. These characteristics are symmetrical to the normal. The fundamental mode $\mathrm{TM}_{0}$ was excited at the synchronous angles of $q_{T M}$ $= \pm 5.63887^{\circ}$, while the excitation of the $\mathrm{TE}_{0}$ mode was carried out at the synchronous angle of $q_{T E}= \pm 0.24499^{\circ}$. The angles were used to calculate effective refractive indices (Equation (3), Ref. [42]) and then the thickness of the waveguide film $d=144.8 \mathrm{~nm}$ and the refractive index $n_{1}=1.9382$ were calculated from the characteristic equations (Equation (6), Ref. [42]). This calculation procedure is based on the assumption that the waveguide film is homogeneous. We infer its homogeneity based on its reflectance spectrum as is described in Section 4.6. As can be observed, the parameters of the waveguide film with a grating coupler are almost identical as those of the film shown in Figure 14. The use of the waveguide films presented here in sensor structures with grating couplers will allow us to achieve high optical sensitivities. The parameters of the waveguide film of the structure shown in Figure 17 are close to the optimal ones in terms of optical sensitivity [42].

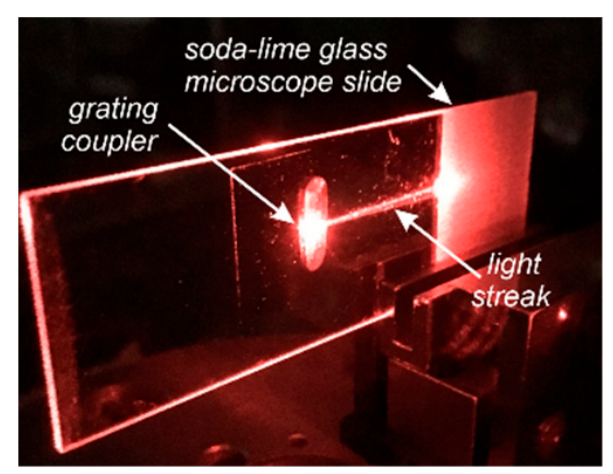

Figure 17. Slab waveguide excited with the use of grating coupler. $\lambda=677 \mathrm{~nm}, \Lambda=417 \mathrm{~nm}$. 


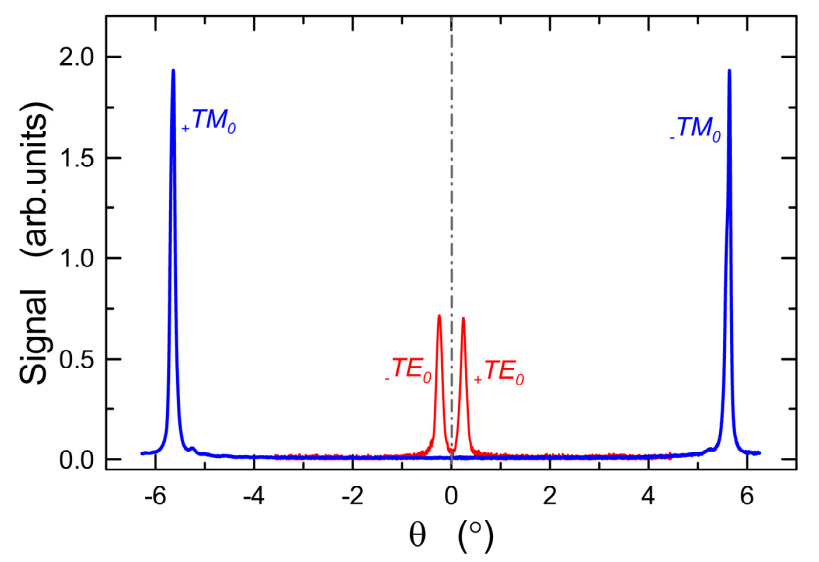

Figure 18. Modal spectra of the slab waveguide excited with the use of the grating coupler for fundamental modes, $\lambda=677 \mathrm{~nm}, \Lambda=417 \mathrm{~nm}$.

\section{Conclusions}

The paper presents the results of the characterization of $\mathrm{SiO}_{\mathrm{x}}: \mathrm{TiO}_{\mathrm{y}}$ composite films fabricated by the sol-gel method and dip-coating technique on soda-lime glass substrates. The studies involving the impact of aging time of the sol demonstrated its impact on viscosity and thus on the final thickness of the films produced at the same withdrawal speed. Yet, the aging of the sol does not affect the final refractive index. The AFM and SEM tests demonstrated high surface smoothness of the produced $\mathrm{SiO}_{\mathrm{x}}: \mathrm{TiO}_{\mathrm{y}}$ films, while the spectrophotometric tests demonstrated their optical homogeneity. The studies of optical energy band gaps by the Tauc method did not display any influence of sol aging time on them. High values of the optical band gaps indicate the amorphous nature of the produced films. This was confirmed by the results of FTIR studies. Fourier spectroscopy studies showed the absence of organic components in the layers after annealing at the temperature of $500{ }^{\circ} \mathrm{C}$. Spectrophotometric tests and the tests with the use of spectroscopic ellipsometry did not indicate the presence of absorption bands in the spectral range above $400 \mathrm{~nm}$. The determined losses for the film thickness slightly above the cut-off thickness are, respectively, $1.1 \mathrm{~dB} / \mathrm{cm}$ for the $\mathrm{TM}_{0}$ mode and $2.7 \mathrm{~dB} / \mathrm{cm}$ for the $\mathrm{TE}_{0}$ mode (at wavelength $\lambda=676.7$ $\mathrm{nm}$ ). We demonstrated a structure with the fabricated grating coupler of the period of $\Lambda=417 \mathrm{~nm}$, which can be applied as a sensor structure. The high refractive index of the waveguide film means that high optical sensitivities can be achieved. The films presented in this paper may become a technological platform for highly sensitive evanescent wave chemical/biochemical sensors in the future. We believe that the use of glass substrates of better surface quality will allow us to obtain lower optical losses.

Author Contributions: Conceptualization, P.K., M.Z. and K.W.; methodology, P.K., M.Z. and K.W.; software, P.K., J.N.; validation, C.T., E.G. and P.K.; formal analysis, M.Z., E.G., J.N., K.S. and P.K.; investigation, M.Z., K.W., C.T., E.G., J.N., K.S., M.W., W.P. and P.K.; writing-original draft preparation, P.K., M.Z., K.W., K.S., C.T. and J.N.; writing-review and editing, C.T., E.G., K.W. and P.K.; visualization, M.Z., C.T., W.P., M.W. and P.K.; supervision, E.G., C.T. and P.K.; project administration, P.K.; funding acquisition, P.K. and C.T. All authors have read and agreed to the published version of the manuscript.

Funding: K.W.: C.T., and P.K. contributed to this article within a scope of the project e TEAM-NET project: "Hybrid sensor platforms of integrated photonic systems based on ceramic and polymer materials (HYPHa)" from the Foundation for Polish Science. Project no: POIR.04.04.00-0014D6/18., whereas M.Z., E.G., J.N., K.S., M.W. and W.P. contributed to this article within a scope of the project OPUS 13 funded by National Science Centre-Poland based on the decision DEC2017/25/B/ST7/02232.

Institutional Review Board Statement: Not applicable.

Informed Consent Statement: Not applicable. 
Data Availability Statement: Data sharing is not applicable to this article.

Acknowledgments: The authors acknowledge the Institute of Nuclear Physics PAN for providing the Raman spectrometer.

Conflicts of Interest: The authors declare no conflict of interest.

\section{References}

1. Edlou, S.M.; Smajkiewicz, A.; Al-Jumaily, G.A. Optical properties and environmental stability of oxide coatings deposited by reactive sputtering. Appl. Opt. 1993, 32, 5601. [CrossRef]

2. Eiamchai, P.; Chindaudom, P.; Pokaipisit, A.; Limsuwan, P. A spectroscopic ellipsometry study of $\mathrm{TiO}_{2}$ thin films prepared by ion-assisted electron-beam evaporation. Curr. Appl. Phys. 2009, 9, 707-712. [CrossRef]

3. Kailasa Ganapathi, S.; Kaur, M.; Shaheera, M.; Pathak, A.; Gadkari, S.C.; Debnath, A.K. Highly sensitive $\mathrm{NO}_{2}$ sensor based on $\mathrm{ZnO}$ nanostructured thin film prepared by SILAR technique. Sens. Actuators B Chem. 2021, 335, 129678. [CrossRef]

4. Fadel, M.; Azim, M.; Omer, O.A.; Basily, R.R. A study of some optical properties of hafnium dioxide $\left(\mathrm{HfO}_{2}\right)$ thin films and their applications. Appl. Phys. A 1998, 66, 335-343. [CrossRef]

5. Luo, X.; Li, Y.; Yang, H.; Liang, Y.; He, K.; Sun, W.; Lin, H.-H.; Yao, S.; Lu, X.; Wan, L.; et al. Investigation of $\mathrm{HfO}_{2}$ thin films on $\mathrm{Si}$ by X-ray photoelectron spectroscopy, rutherford backscattering, grazing incidence $\mathrm{X}$-ray diffraction and variable angle spectroscopic ellipsometry. Crystals 2018, 8, 248. [CrossRef]

6. Boratto, M.H.; Congiu, M.; dos Santos, S.B.O.; Scalvi, L.V.A. Annealing temperature influence on sol-gel processed zirconium oxide thin films for electronic applications. Ceram. Int. 2018, 44, 10790-10796. [CrossRef]

7. Venkataraj, S.; Kappertz, O.; Weis, H.; Drese, R.; Jayavel, R.; Wuttig, M. Structural and optical properties of thin zirconium oxide films prepared by reactive direct current magnetron sputtering. J. Appl. Phys. 2002, 92, 3599-3607. [CrossRef]

8. Bright, T.J.; Watjen, J.I.; Zhang, Z.M.; Muratore, C.; Voevodin, A.A.; Koukis, D.I.; Tanner, D.B.; Arenas, D.J. Infrared optical properties of amorphous and nanocrystalline $\mathrm{Ta}_{2} \mathrm{O}_{5}$ thin films. J. Appl. Phys. 2013, 114, 083515. [CrossRef]

9. Nisar, J.; Topalian, Z.; De Sarkar, A.; Österlund, L.; Ahuja, R. TiO2-based gas sensor: A possible application to SO 2 . ACS Appl. Mater. Interfaces 2013, 5, 8516-8522. [CrossRef]

10. Shamma, K.; Aldwayyan, A.; Albrithen, H.; Alodhayb, A. Exploiting the properties of $\mathrm{TiO}_{2}$ thin films as a sensing layer on (MEMS)-based sensors for radiation dosimetry applications. AIP Adv. 2021, 11, 025209. [CrossRef]

11. Mitra, P.; Chatterjee, A.P.; Maiti, H.S. ZnO thin film sensor. Mater. Lett. 1998, 35, 33-38. [CrossRef]

12. Kolhe, P.S.; Shinde, A.B.; Kulkarni, S.G.; Maiti, N.; Koinkar, P.M.; Sonawane, K.M. Gas sensing performance of Al doped ZnO thin film for $\mathrm{H}_{2} \mathrm{~S}$ detection. J. Alloys Compd. 2018, 748, 6-11. [CrossRef]

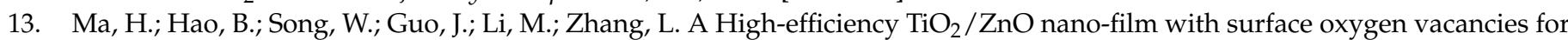
dye degradation. Materials 2021, 14, 3299. [CrossRef]

14. Philip, A.; Ghiyasi, R.; Karppinen, M. Photoactive thin-film structures of curcumin, $\mathrm{TiO}_{2}$ and ZnO. Molecules 2021, $26,3214$. [CrossRef]

15. Löckinger, J.; Nishiwaki, S.; Weiss, T.P.; Bissig, B.; Romanyuk, Y.E.; Buecheler, S.; Tiwari, A.N. TiO 2 as intermediate buffer layer in $\mathrm{Cu}(\mathrm{In}, \mathrm{Ga}) \mathrm{Se}_{2}$ solar cells. Sol. Energy Mater. Sol. Cells 2018, 174, 397-404. [CrossRef]

16. Sharma, K.; Sharma, V.; Sharma, S.S. Dye-sensitized solar cells: Fundamentals and current status. Nanoscale Res. Lett. 2018, 13, 381. [CrossRef]

17. Drygała, A.; Szindler, M.; Szindler, M.; Jonda, E. Atomic layer deposition of $\mathrm{TiO}_{2}$ blocking layers for dye-sensitized solar cells. Microelectron. Int. 2020, 37, 87-93. [CrossRef]

18. Gondek, E.; Karasiński, P. High reflectance materials for photovoltaics applications: Analysis and modelling. J. Mater. Sci. Mater. Electron. 2013, 24, 2934-2943. [CrossRef]

19. Shen, H.; Wang, Z.; Wu, Y.; Yang, B. One-dimensional photonic crystals: Fabrication, responsiveness and emerging applications in 3D construction. RSC Adv. 2016, 6, 4505-4520. [CrossRef]

20. Skolik, M.; Domanowska, A.; Karasiński, P.; Gondek, E.; Michalewicz, A. Double layer sol-gel derived antireflective coatings on silicon-Design, optical and Auger Electron Spectroscopy characterization. Mater. Lett. 2019, 251, 210-213. [CrossRef]

21. Chee, K.W.A.; Tang, Z.; Lü, H.; Huang, F. Anti-reflective structures for photovoltaics: Numerical and experimental design. Energy Rep. 2018, 4, 266-273. [CrossRef]

22. Touam, T.; Znaidi, L.; Vrel, D.; Ninova-Kuznetsova, I.; Brinza, O.; Fischer, A.; Boudrioua, A. Low loss sol-gel TiO 2 thin films for waveguiding applications. Coatings 2013, 3, 49-58. [CrossRef]

23. Bradley, J.D.B.; Evans, C.C.; Choy, J.T.; Reshef, O.; Deotare, P.B.; Parsy, F.; Phillips, K.C.; Lončar, M.; Mazur, E. Submicrometer-wide amorphous and polycrystalline anatase $\mathrm{TiO}_{2}$ waveguides for microphotonic devices. Opt. Express 2012, 20, 23821. [CrossRef]

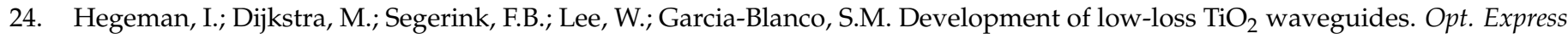
2020, 28, 5982. [CrossRef]

25. Heideman, R.G.; Lambeck, P.V.; Gardeniers, J.G.E. High quality ZnO layers with adjustable refractive indices for integrated optics applications. Opt. Mater. 1995, 4, 741-755. [CrossRef]

26. Ferrari, J.L.; Lima, K.D.O.; Gonçalves, R.R. Refractive indexes and spectroscopic properties to design $\mathrm{Er}^{3+}-\mathrm{doped}_{\mathrm{SiO}} \mathrm{-Ta}_{2} \mathrm{O}_{5}$ films as multifunctional planar waveguide platforms for optical sensors and amplifiers. ACS Omega 2021, 6, 8784-8796. [CrossRef] 
27. Sierra, J.H.; Rangel, R.C.; Samad, R.E.; Vieira, N.D.; Alayo, M.I.; Carvalho, D.O. Low-loss pedestal Ta $2 \mathrm{O}_{5}$ nonlinear optical waveguides. Opt. Express 2019, 27, 37516. [CrossRef]

28. Urlacher, C.; Marco De Lucas, C.; Bernstein, E.; Jacquier, B.; Mugnier, J. Study of erbium doped $\mathrm{ZrO}_{2}$ waveguides elaborated by a sol-gel process. Opt. Mater. 1999, 12, 19-25. [CrossRef]

29. Ma, X.; Zhang, Q.; Guo, P.; Tong, X.; Zhao, Y.; Wang, A. Residual compressive stress enabled 2D-to-3D junction transformation in amorphous carbon films for stretchable strain sensors. ACS Appl. Mater. Interfaces 2020, 12, 45549-45557. [CrossRef] [PubMed]

30. MacManus-Driscoll, J.L.; Wells, M.P.; Yun, C.; Lee, J.W.; Eom, C.B.; Schlom, D.G. New approaches for achieving more perfect transition metal oxide thin films. APL Mater. 2020, 8, 040904. [CrossRef]

31. Chao, S.; Wang, W.-H.; Hsu, M.-Y.; Wang, L.-C. Characteristics of ion-beam-sputtered high-refractive-index $\mathrm{TiO}_{2}-\mathrm{SiO}_{2} \mathrm{mixed}$ films. J. Opt. Soc. Am. A 1999, 16, 1477. [CrossRef]

32. Yang, L.L.; Lai, Y.S.; Chen, J.S.; Tsai, P.H.; Chen, C.L.; Chang, C.J. Compositional tailored sol-gel SiO $2-\mathrm{TiO}_{2}$ thin films: Crystallization, chemical bonding configuration, and optical properties. J. Mater. Res. 2005, 20, 3141-3149. [CrossRef]

33. Louis, B.; Krins, N.; Faustini, M.; Grosso, D. Understanding crystallization of anatase into binary $\mathrm{SiO}_{2} / \mathrm{TiO}_{2}$ sol-gel optical thin films: An in situ thermal ellipsometry analysis. J. Phys. Chem. C 2011, 115, 3115-3122. [CrossRef]

34. Royon, M.; Jamon, D.; Blanchet, T.; Royer, F.; Vocanson, F.; Marin, E.; Morana, A.; Boukenter, A.; Ouerdane, Y.; Jourlin, Y.; et al. Sol-gel waveguide-based sensor for structural health monitoring on large surfaces in aerospace domain. Aerospace $2021,8,109$. [CrossRef]

35. Poddighe, M.; Innocenzi, P. Hydrophobic thin films from sol-gel processing: A critical review. Materials 2021, 14, 6799. [CrossRef]

36. Alberti, S.; Jagerska, J. Sol-gel thin film processing for integrated waveguide sensors. Front. Mater. 2021, 8, 629822. [CrossRef]

37. Chen, D. Anti-reflection (AR) coatings made by sol-gel processes: A review. Sol. Energy Mater. Sol. Cells 2001, 68, 313-336. [CrossRef]

38. Karasiński, P. Sensor properties of planar waveguide structures with grating couplers. Opto-Electron. Rev. 2007, 15, 168-178. [CrossRef]

39. Tyszkiewicz, C.; Karasiński, P.; Rogoziński, R. Directional couplers fabricated via a sol-gel route and conventional optical lithography. Opt. Quantum Electron. 2016, 48, 1-14. [CrossRef]

40. Karasiński, P.; Tyszkiewicz, C.; Domanowska, A.; Michalewicz, A.; Mazur, J. Low loss, long time stable sol-gel derived silica-titania waveguide films. Mater. Lett. 2015, 143, 5-7. [CrossRef]

41. Karasiński, P.; Domanowska, A.; Gondek, E.; Sikora, A.; Tyszkiewicz, C.; Skolik, M. Homogeneity of sol-gel derived silica-titania waveguide films-Spectroscopic and AFM studies. Opt. Laser Technol. 2020, 121, 105840. [CrossRef]

42. Karasiński, P.; Kaźmierczak, A.; Zięba, M.; Tyszkiewicz, C.; Wojtasik, K.; Kielan, P. Highly sensitive sensor structure based on sol-gel waveguide films and grating couplers. Electronics 2021, 10, 1389. [CrossRef]

43. Carrera-Figueiras, C.; Pérez-Padilla, Y.; Alejandro Estrella-Gutiérrez, M.; Uc-Cayetano, G.E.; Antonio Juárez-Moreno, J.; AvilaOrtega, A. Surface science engineering through sol-gel process. In Applied Surface Science; InTech Open: London, UK, 2019. [CrossRef]

44. Brinker, C.J.; Scherer, G.W. Sol-Gel Science: The Physics and Chemistry of Sol-Gel Processing; Wiley \& Sons Library: Hoboken, NJ, USA, 2013; pp. 1-908. [CrossRef]

45. Klein, L.; Aparicio, M.; Jitianu, A. Handbook of Sol-Gel Science and Technology-Processing, Characterization and Applications; Klein, L., Aparicio, M., Jitianu, A., Eds.; Springer International Publishing: New York, NY, USA, 2018.

46. Dip Coating: Practical Guide to Theory and Troubleshooting / Ossila. Available online: https://www.ossila.com/pages/dipcoating (accessed on 14 May 2021).

47. Karasiński, P. Sol-gel derived optical waveguide films for planar sensors with phase modulation. Opt. Applocata 2004, 34, 467-475.

48. Guglielmi, M.; Zenezini, S. The thickness of sol-gel silica coatings obtained by dipping. J. Non-Cryst. Solids 1990, 121, 303-309. [CrossRef]

49. Bindini, E.; Naudin, G.; Faustini, M.; Grosso, D.; Boissière, C. Critical role of the atmosphere in dip-coating process. J. Phys. Chem. C 2017, 121, 14572-14580. [CrossRef]

50. Azzam, R.M.A.; Bashara, N.M. Ellipsometry and Polarized Light (North-Holland Personal Library); 9780444870162. Available online: https: / / www.amazon.com/Ellipsometry-Polarized-North-Holland-Personal-Library / dp/0444870164 (accessed on 14 May 2021).

51. Jellison, G.E.; Modine, F.A. Parameterization of the optical functions of amorphous materials in the interband region. Appl. Phys. Lett. 1996, 69, 371. [CrossRef]

52. Jellison, G.E.; Merkulov, V.I.; Puretzky, A.A.; Geohegan, D.B.; Eres, G.; Lowndes, D.H.; Caughman, J.B. Characterization of thin-film amorphous semiconductors using spectroscopic ellipsometry. Thin Solid Films 2000, 377-378, 68-73. [CrossRef]

53. Von Blanckenhagen, B.; Tonova, D.; Ullmann, J. Application of the Tauc-Lorentz formulation to the interband absorption of optical coating materials. Appl. Opt. 2002, 41, 3137-3141. [CrossRef] [PubMed]

54. Schmiedova, V.; Heinrichova, P.; Zmeskal, O.; Weiter, M. Characterization of polymeric thin films for photovoltaic applications by spectroscopic ellipsometry. Appl. Surf. Sci. 2015, 349, 582-588. [CrossRef]

55. Nizioł, J. Thermal treatment effects imposed on solid DNA cationic lipid complex with hexadecyltrimethylammonium Chloride, observed by variable angle spectroscopic ellipsometry. J. Appl. Phys. 2014, 116, 234701. [CrossRef] 
56. Tauc, J.; Grigorovici, R.; Vancu, A. Optical properties and electronic structure of amorphous germanium. Phys. Status Solidi 1966, 15, 627-637. [CrossRef]

57. Shajari-Ghasemkheili, S.; Sarraf-Mamoory, R. Development of a transparent silica-titania-methyl siliconate nanocoating with photocatalytic-hydrophobic properties aided by response surface method. Mater. Res. Express 2019, 6, 106430. [CrossRef]

58. Asthana, Y.; Hong, L.Y.; Kim, D.P.; Lee, T.S.; Sung, Y.M. Formulation of thermally cured organic-inorganic superhydrophilic coating for antifogging optical application. Mol. Cryst. Liq. Cryst. 2007, 463, 117/[399]-129/[411]. [CrossRef]

59. Aizawa, M.; Nosaka, Y.; Fujii, N. FT-IR liquid attenuated total reflection study of $\mathrm{TiO}_{2}: \mathrm{SiO}_{2}$ sol-gel reaction. J. Non-Cryst. Solids 1991, 128, 77-85. [CrossRef]

60. Kermadi, S.; Agoudjil, N.; Sali, S.; Zougar, L.; Boumaour, M.; Broch, L.; En Naciri, A.; Placido, F. Microstructure and optical dispersion characterization of nanocomposite sol-gel $\mathrm{TiO}_{2}-\mathrm{SiO}_{2}$ thin films with different compositions. Spectrochim. Acta-Part A Mol. Biomol. Spectrosc. 2015, 145, 145-154. [CrossRef]

61. Wang, Z.; Pakoulev, A.; Pang, Y.; Dlott, D.D. Vibrational substructure in the OH stretching transition of water and HOD. J. Phys. Chem. A 2004, 108, 9054-9063. [CrossRef]

62. Hardcastle, F.D.; Ishihara, H.; Sharma, R.; Biris, A.S. Photoelectroactivity and Raman spectroscopy of anodized titania (TiO 2 ) photoactive water-splitting catalysts as a function of oxygen-annealing temperature. J. Mater. Chem. 2011, 21, 6337-6345. [CrossRef]

63. Yamada, T.; Makoto, N.; Suemoto, T.; Uchino, T. Formation and photoluminescence characterization of transparent silica glass prepared by solid-phase reaction of nanometer-sized silica particles. J. Phys. Chem. C 2007, 111, 12973-12979. [CrossRef]

64. Payne, F.P.; Lacey, J.P.R. A theoretical analysis of scattering loss from planar optical waveguides. Opt. Quantum Electron. 1994, 26, 977-986. [CrossRef]

65. Palik, E.D. Handbook of Optical Constants of Solids; Academic Press: Orlando, FL, USA, 1985. 